\title{
МЕДИКО-ОРГАНІЗАЦІЙНІ НЕДОЛІКИ ПРОФІЛАКТИКИ ХВОРОБ СИСТЕМИ КРОВООБІГУ В УКРАЇНІ ТА ШЛЯХИ ЇХ ПОДОЛАННЯ
}

\author{
Запорізький державний медичний університет, Україна
}

\begin{abstract}
Мета: встановити медико-організаційні недоліки профілактики хвороб системи кровообігу на регіональному рівні та розробити шляхи їх подолання.

Матеріали і методи. Проведено аналіз стану здоров'я населення працездатного віку за даними звітів центрів медичної статистики та медико-соціальної експертизи Запорізької області; медико-соціальне опитування 525 осіб працездатного віку та 100 лікарів терапевтичного профілю. У дослідженні використано бібліосемантичний, медикостатистичний, соціологічний методи.

Результати. Доведено, що хвороби системи кровообігу залишаються значущою медико-соціальною проблемою. Визначено поширеність провідних керованих чинників ризику серед населення працездатного віку, що страждає на хвороби системи кровообігу. На прикладі гіпертонічної хвороби, як найпоширенішої нозології, показано неефективність профілактичних заходів, а провідним медико-організаційним недоліком є недостатній рівень інформування населення працездатного віку про чинники ризику хвороб системи кровообігу, що призводить до хибного уявлення про вплив способу життя на стан здоров'я.

Висновки. Стратегічним напрямком удосконалення організації профілактики хвороб системи кровообігу на міжсекторальному рівні повинно стати об'єднання зусиль громадських і релігійних організацій та медичних закладів.

КЛЮЧОВІ СЛОВА: хвороби системи кровообігу, інформаційно-освітнє забезпечення, профілактика, населення працездатного віку.
\end{abstract}

В Україні протягом 2012 року хвороби системи кровообігу (ХСК) обумовили 66,7\% усіх смертей, серед населення працездатного віку $29,7 \%$, посідаючи одне з перших місць в країнах Європи [1]. У структурі поширеності ХСК домінують гіпертонічна хвороба (ГХ) - 46,2\%, ішемічна хвороба серця (IXC) - 33,8\% та цереброваскулярні захворювання (ЦВЗ) - 12,7\%. У той час, коли в країнах Західної Європи смертність населення у зв'язку з ХСК динамічно знижується, в Україні спостерігається зворотна тенденція [9;14].

В основі ГХ лежить підвищення артеріального тиску (АТ), що є основним чинником ризику (ЧР) розвитку IXC, інфаркту міокарда, а також ЦВЗ, зокрема мозкового інсульту, і, звичайно, безпосередньо впливає на показники захворюваності, інвалідності та смертності внаслідок ХСК [1;9;11]. Причиною розвитку цих та інших ускладнень, а також смертності від ХСК, $€$ різні ЧР, у тому числі їх поєднання. Основні ЧР розвитку ХСК легко модифікуються і не потребують значних фінансових витрат з боку держави і пацієнтів. ВООЗ визначено 7 провідних ЧР, що роблять основний внесок у передчасну смертність населення, серед яких: підвищений АТ (35,5\%), гіперхолестеринемія (23\%), паління $(17,1 \%)$, нездорове харчування, недостатнє вживання фруктів та овочів (12,9\%), ожиріння (12,5\%), зловживання алкоголем (11,9\%), низька фізична активність (9\%) [6]. Чинники ризику можуть накопичуватися у індивідуумів і взаємодіяти один з одним, створюючи множинний ефект: наявність декількох ЧР

(C) А.В. Коваленко, В.І. Клименко, 2014 у однієї людини підвищує ризик її смерті від ХСК у 5-7 разів [3]. Це покладено в основу концепції ЧР, на підставі якої розроблена та впроваджується низка профілактичних програм, результатом яких є зменшення масштабів багатьох проблем громадського здоров'я [3;4].

Складна епідеміологічна ситуація щодо ХCK та їх ускладнень може бути покращена шляхом профілактики та фахової раціональної базової фармакотерапії (фармакопрофілактики), оскільки усунення ЧР в популяції та поліпшення детермінантів здоров'я супроводжуються зниженням рівнів захворюваності і смертності населення [7;8;17]. Досвідом багатьох країн (Фінляндія, США, Великобританія, Нова Зеландія та ін.) доведено, що модифікація способу життя і зниження рівнів ЧР можуть загальмувати розвиток ХCК, як до, так і після появи клінічних симптомів [5].

Основою пропаганди здорового способу життя (ЗСЖ), нарівні з інформуванням населення про шкоду споживання тютюну, нераціонального і незбалансованого харчування, низької фізичної активності, зловживання алкоголем, наркотиками і токсичними речовинами, повинно стати навчання навичкам з дотримання правил гігієни, режиму праці і навчання [2;6]. Крім цього, пріоритет повинен надаватися не лише своєчасному виявленню ЧР та неінфекційних хвороб, але і своєчасній їх корекції. Ефективність міжсекторального підходу щодо формування інформаційно-просвітницької роботи та ЗСЖ у населення доведено у багатьох країнах світу [12]. Так, S.J. Flynn et al. пропонували навчити населення та хворих на ГX контролювати АТ з метою подальшого само- 
менеджменту та поширення отриманих ними знань в колі аналогічних хворих [13].

Актуальним залишається питання щодо вивчення поширеності провідних модифікованих ЧР серед населення працездатного віку, встановлення рівня інформованості населення про них медичними працівниками з метою розробки шляхів подолання виявлених медико-організаційних недоліків профілактики ХСК.

Мета дослідження - встановити медикоорганізаційні недоліки профілактики хвороб системи кровообігу на регіональному рівні та розробити шляхи їх подолання.

Матеріали і методи. Нами на підставі вивчення даних довідників статистичних звітів центру медичної статистики та Головного статистичного управління Запорізької області за 2005-2013 рр., статистичних звітів Запорізького обласного центру медико-соціальної експертизи за 2005-2013 рр. проведено аналіз стану здоров'я населення працездатного віку в зв'язку з ХСК. Для отримання рівня поширеності провідних ЧР ХСК серед населення працездатного віку та інформованості про них проведено медико-соціальне дослідження 525 осіб працездатного віку Запорізької області.

Для вивчення впливу організації медичної допомоги на інформованість населення працездатного віку про ЧР ХСК проведено соціологічне опитування 100 лікарів терапевтичного профілю, що надають медичну допомогу хворим на ХCK на первинному та вторинному рівнях.

Методи дослідження обґрунтовані системним підходом та аналізом, що дозволило застосувати комплекс адекватних методів дослідження: бібліосемантичний - для вивчення світового досвіду стосовно розробки та впровадження різних ефективних заходів з профілактики ХCК; медикостатистичний - для динамічного та структурного аналізу стану здоров'я населення працездатного віку Запорізької області в зв'язку з ХСК порівняно із середнім по Україні; соціологічний - для вивчення інформованості населення працездатного віку про керовані ЧР ХСК лікарями терапевтичного профілю первинного та вторинного рівнів, що надають медичну допомогу кардіологічним хворим.

Результати дослідження та їх обговорення. На підставі аналізу показників популяційного здоров'я показано, що протягом 2005-2013 рр. рівень загальної смертності серед всього населення Запорізької області знизився на 159,8 на 100 тис. нас., а в зв'язку з ХСК зріс на 162,5 на 100 тис. нас., що призвело до зростання питомої ваги ХСК у структурі смертності з 48,84\% (2005 р.) до 65\% (2013 р.). Станом на 01.2013 р. питома вага XCK в смертності населення працездатного віку по Україні становила 30,5\%, по Запорізькій області - 33,4\%: серед чоловіків $35,73 \%$, серед жінок - 24,15\%. Рівень смертності від ХСК серед чоловіків Запорізької області працездатного віку в 5,5 разу перевищував аналогічний показник серед жінок даної вікової категорії. Встановлено гендерні відмінності в структурі смертності від ХСК серед населення працездатного віку: жінки частіше помирають від ЦВЗ, а чоловіки - від IXC.

Вивчення змін показників первинної та загальної захворюваності за провідними нозологіями XСК (ГX, ІХC та ЦВЗ) протягом 2005-2013 рр. свідчить про їх щорічні коливання. Питома вага ГХ у структурі загальної захворюваності на ХСК серед населення працездатного віку Запорізької області станом на 01.2013 р. становила 56,4\%; IXC - 26, 1\%, ЦВ3 - 7,98\% та не мала вірогідної різниці між районами та містами області. Така ситуація склалася через неефективну профілактичну роботу в районах області. Підтвердженням цього є отримані нами дані охоплення диспансеризацією населення працездатного віку. міст та районів Запорізької області за 2010 р. 4964,54 (на 10 тис. нас. працездатного віку) та 4385,42 (на 10 тис. нас. працездатного віку) відповідно, що підкреслює недоступність та низьку ефективність медичної допомоги в сільській місцевості. Якщо на диспансерному обліку переважно знаходиться населення з діагнозом ГХ, рівень первинної та загальної захворюваності на яку щорічно зростає, то в структурі інвалідності в зв'язку з ХСК перше місце посідають ЦВЗ, друге - IXC, а сама ГX Є ЧР розвитку даних хвороб. Таким чином, попереджаючи розвиток ГХ та проводячи ефективну вторинну профілактику, можливо запобігти її ускладненню.

Про важливість профілактичних заходів, як основи охорони здоров'я населення, свідчить поширення ЧР серед популяції. Нами встановлено, що 35,64 4,77\% населення працездатного віку

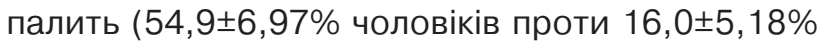
жінок, $p<0,001)$. Більшість населення розпочала курити у віці до 25 років, найбільш вразливим $€$

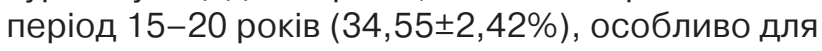
чоловіків $(42,62 \pm 3,66 \%$ проти $27,23 \pm 3,13 \%$ у жінок

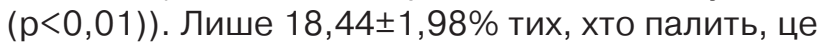
турбує постійно, 40,26士2,50\% респондентів замислюються над цим, а 18,44ะ1,98\% взагалі це не турбує. Гендерних відмінностей не встановлено.

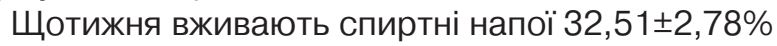
опитаних, з яких 54,46 4,96\% під час зустрічі 3

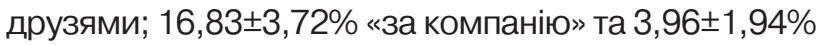
для зняття психоемоційного стресу в кінці тижня. Не звертають увагу на необхідність дотримання дієти 57,66士2,52\% опитаних, харчуються нерізноманітно та незбалансовано через брак коштів $19,74 \pm 2,03 \%(25,25 \pm 3,06 \%$ - жінок проти $13,66 \pm 2,54 \%$ чоловіків, $p<0,05)$, брак часу на приготування їжі - 18,18ะ1,97\%; лінуються закуповувати потрібні та корисні продукти через відда-

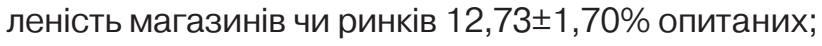


брак часу через роботу $-10,91 \pm 1,59 \%$ (13,86 2 , $43 \%$ жінок проти $7,65 \pm 1,96 \%$ чоловіків, $p<0,05)$.

Рівень, збалансованість та регулярність харчування завжди відбиваються на масі тіла. Соціологічним опитуванням населення підтверджено, що проблема надмірної ваги турбує переважно жінок: 49,50 $33,52 \%$ контролює свою масу тіла проти $34,43 \pm 3,51 \%$ чоловіків $(p<0,01)$. Таке ставлення, швидше, $є$ наслідком естетичних прагнень, ніж турботою про стан свого здоров'я. Підтвердженням цьому може стати опитування щодо контролю за рівнем холестерину, рівень якого не контролюють $60,11 \pm 3,62 \%$ опитаних.

На стан здоров'я населення позитивно впливають заняття фізичною культурою, але $40,52 \pm 2,50 \%$ опитаних вважають, що якщо вони «ведуть активний спосіб життя», їм не потрібні додаткові заняття спортом, а 20,78 2, 07\% відверто відносять свій спосіб життя до малорухливого, і лише $14,55 \pm 1,80 \%$ респондентів регулярно відвідують різні спортивні заклади, серед яких достовірно

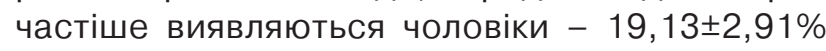
проти $10,40 \pm 2,15 \%$ жінок ( $p<0,05)$.

Стан здоров'я в майбутньому турбує тільки $43,90 \pm 2,53 \%$ населення працездатного віку, а 28,83 2 2,31\% респондентів інколи замислюються над цим питанням, $6,75 \pm 1,28 \%$ опитаного населення взагалі не турбує стан власного здоров'я, а 20,52 $\pm 2,06 \%$ не визначилися, тобто навіть не усвідомлюють, що здоров'я - це найбільший скарб, який $є$ у людини, вважаючи, що це закономірний природний стан організму, який виникає незалежно від способу життя (42,6 $\pm 4,92 \%)$. Підтвердженням недбайливого та безтурботного ставлення до стану власного здоров'я є дані, що лише 41,82 $2,51 \%$ респондентів при погіршенні стану свого здоров'я звертаються до медичного закладу, 17,66ะ1,94\% йдуть до аптеки і самостійно приймають ліки симптоматично, $14,03 \pm 1,77 \%$ лікуються народними засобами,

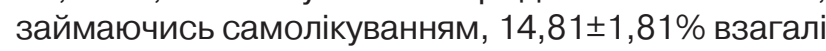
нічого не роблять і чекають «поки все минеться»,

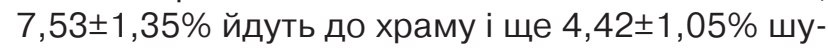
кають поради в Інтернеті.

На відвідування закладів охорони здоров'я впливає медична грамотність самого населення [15;16], яку повинні підвищувати лікарі. Згідно 3 уніфікованим клінічним протоколом медичної допомоги хворим на ГХ, первинна профілактика розглядається з позиції загальної профілактики серцево-судинних захворювань і полягає у виявленні і корекції доведених ЧР: тютюнопаління; гіперхолестеринемія; надлишкова маса тіла; недостатня фізична активність; зловживання алкоголем, а до обов'язкових дій лікаря первинної ланки належить надання пацієнту в доступній формі інформації про стан його здоров'я з рекомендаціями щодо немедикаментозного і медикаментозного лікування, тактики поведінки при раптовому погіршенні перебігу захворювання в усній та письмовій формі [10]. Нами доведено, що зниження ефективності лікування є наслідком низького рівня інформованості та медичної грамотності населення про ЧР ХСК, ЗСЖ, доцільність контролю АТ та прийому антигіпертензивних препаратів. Підтвердженням $\in$ той факт, що лише $32,95 \pm 5,01 \%$ опитаних контролює рівень АТ і лише при погіршенні самопочуття, яке відчуває $67,65 \pm 8,02 \%$ населення. Регулярно приймають антигіпертензивні препарати 55,88 8,52\% респондентів. Нами встановлено провідні причини небажання лікуватися: відсутність грошей та страх побічних дій препаратів у рівній мірі - по $33,33 \pm 13,61 \%$. У зв'язку з цим 25,0 $12,5 \%$ хворих на АГ лікуються альтернативними методами. Як наслідок всього вищезазначеного, у 50,0 $8,57 \%$ хворих реєструються гіпертонічні кризи один $(52,94 \pm 12,11 \%)$ або два $(41,18 \pm 11,94 \%)$ рази на рік, які тільки $3,57 \pm 3,51 \%$ опитаних пов'язують 3 нерегулярним прийомом антигіпертензивних препаратів. Підтвердженням неефективного лікування та відсутності профілактичних дій серед пацієнтів працездатного віку $є$ той факт, що $8,82 \pm 4,86 \%$ хворих на ГХ перенесли інфаркт міокарда або інсульт протягом року після встанов-

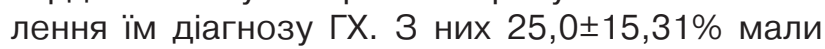
повторне ускладнення в той же рік, 37,5 $17,12 \%-$ протягом двох років, а $37,5 \pm 17,12 \%$ - через три роки. Навіть наявність ускладнення не підвищила мотивацію до лікувально-профілактичних за-

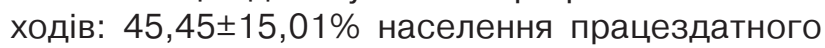
віку відвідало лікаря після ускладнення одноразово, після виписки із стаціонару.

Таким чином, нашим медико-соціальним дослідженням доведено низький рівень ЗСЖ та обізнаності населення про ЧР ХСК, навіть при достатньому рівні інформованості про них, небажання дотримуватися їх, що підтверджується ставленням до стану свого здоров'я.

Нами запропоновано оптимізацію організації комплексної профілактики ХСК. Стратегічний напрямок змін спрямовується на покращення стану здоров'я населення працездатного віку через реалізацію комплексу інформаційно-освітнього забезпечення профілактики ХСК. Тактичним напрямком $€$ залучення для формування ЗСЖ у населення України не тільки медичних працівників, але й громадських та релігійних організацій, і суспільства загалом, а також розподіл ролей і функціональних взаємозв'язків між всіма зацікавленими в досягненні інформаційноосвітнього забезпечення формування ЗСЖ для профілактики XСК населення України. Найважливішою складовою усіх профілактичних заходів є формування у населення медико-соціальної активності й установок на ЗСЖ.

Нами було показано ефективність залучення релігійних організацій до формування ЗСЖ се- 
ред населення працездатного віку, що щиро сповідує принципи православного християнства, серед якого менш поширені шкідливі звички: 11,3\% палять, а алкогольні напої вживають тільки на великі церковні свята - 73,6士2,32\%, решта взагалі їх не вживає. За даними нашого медикосоціального дослідження встановлено зростання рівня інформованості про ЧР ХСК серед даної когорти населення на 33,4\% (95\% Cl: 27,4-39,4\%); в 18,9 разу зростає рівень вироблення мотивації до ЗСЖ (OR=18,88; 95\% Cl: 8,84-40,31). Підтвер-

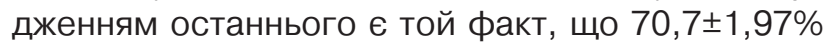
опитаних відмовилися від шкідливих звичок після того, як усвідомили себе віруючою людиною.

\section{Висновки}

1. Проведене медико-соціальне дослідження довело поширеність провідних керованих чинників ризику хвороб системи кровообігу серед населення працездатного віку на тлі низького рівня обізнаності про них.

2. Показано неефективність профілактичних заходів серед хворих на гіпертонічну хворобу: 8,82 4,86\% пацієнтів з вперше в житті встановленим діагнозом протягом року мали ускладнення, серед яких у кожного четвертого спостерігалося повторне ускладнення в той самий рік, а у кожного третього - протягом 2-3 років. Наявність ускладнення не підвищує мотивацію до корекції способу життя за допомогою медичних працівників:

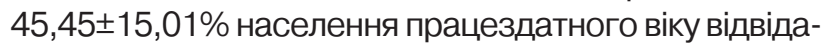
ло лікаря одноразово при виписці із стаціонару.

3. Провідними медико-організаційними недоліками профілактичної роботи є недостатній рівень інформування населення працездатного віку про чинники ризику хвороб системи кровообігу, що відбивається на своєчасній звертальності за медичною допомогою та призводить до хибного уявлення щодо впливу способу життя на стан здоров'я і, як наслідок, до низького рівня мотивації зміни свого способу життя.

4. Об'єднання зусиль громадських, релігійних організацій та медичних працівників повинно стати основою регіональної комплексної цільової програми «Формування здорового способу життя та профілактики хвороб системи кровообігу», в якій будуть враховані культурні, етнічні, духовні та інші особливості регіону, та стане ефективним шляхом профілактики хвороб системи кровообігу, що становитиме перспективи подальших досліджень.

\section{Список літератури}

1. Европейская база данных “Здоровье для всех" [Электронный ресурс]. - Копенгаген, ЕРБ ВОЗ, 2009. - Режим доступа: http://www.euro.who.int/hfadb?language= Russian (по состоянию на 9 июля 2009 г.).

2. Кобалава Ж. Д. Является ли обучение больных фактором, повышающим эффективность контроля артериальной гипертонии? / Ж. Д. Кобалава, С. В. Виллевальде // Кардиология (Kardiologiia). - 2007. - № 10. - С. 75-82.

3. Мамедов М. Н. Оценка суммарного риска развития сердечно-сосудистых заболеваний у взрослых лиц трудоспособного возраста: уроки исследования КРОССВОРД / М. Н. Мамедов, А. Д. Деев // Кардиология (Kardiologiia). 2008. - № 10. - С. 28-33.

4. Оганов Р. Г. Современные стратегии профилактики и лечения сердечно-сосудистых заболеваний / Р. Г. Оганов, Г.В.Погосова // Кардиология (Kardiologiia). - 2007. - № 12. - С. 4-9.

5. Профилактика и лечение артериальной гипертензии в амбулаторных условиях с использованием мобильной телефонной связи и интернет-технологий / А. Р. Киселев, В.А.Шварц, О. М. Посненкова [и др.] // Терапевтич. арх. - 2011. - № 4. - С. 46-52.

6. Радченко Г. Д. Визначення лікарями серцево-судинного ризику у пацієнтів з артеріальною гіпертензією: чи можуть лекції допомогти покращити ситуацію / Г. Д. Радченко, І. М. Марцовенко, Ю. М. Сіренко // Укр. кардіолог. журн. - 2011. - № 1. - С. 43-48.

7. РЕЛИФ - Регулярное Лечение и проФилактика - ключ к улучшению ситуации с сердечно-сосудистыми заболеваниями в России: результаты российского многоцентрового исследования. Часть 1 / Р. Г. Органов, Г. В. Погосова, И. Е. Колтунов [и др.] // Кардиология (Kardiologiia). - 2007. - № 5. - С. 58-66.

8. РЕЛИФ - Регулярное Лечение и проФилактика - ключ к улучшению ситуации с сердечно-сосудистыми заболеваниями в России: результаты российского многоцентрового исследования. Часть 3 / Р. Г. Органов, Г.В.Погосова, И. Е. Колтунов [и др.] // Кардиология (Kardiologiia). - 2008. - № 4. - С. 46-53.

9. Сердечно-сосудистая заболеваемость и смертность - статистика по европейски странам (2008) // Medicine review. - 2009. - № 1 (06) - С. 6-12.

10. Уніфікований клінічний протокол медичної допомоги. Артеріальна гіпертензія. Первинна медична допомога (догоспітальний єтап). Вторинна (спеціалізована) медична допомога (2012 рік) // Артериальная гипертензия. 2012. - № 1. - С. 67-95.

11. Федчишин Н. Є. Хвороби системи кровообігу: динаміка поширеності в Україні та Тернопільській області / Н. Є. Федчишин // Вісн. соц. гігієни та орг. охорони здоров'я України. - 2013. - № 1. - С. 53-55.

12. Creating a transdisciplinary research center to reduce cardiovascular health disparities in Baltimore, Maryland: lessons learned / L. A. Cooper, L. E. Boulware, E. R. Miller [et al.] // Am. J. Public Health. - 2013. - Vol. 103 (11). - P. $26-63$.

13. Facilitators and barriers to hypertension self-management in urban African Americans: perspectives of patients and family members / S. J. Flynn, J. M. Ameling, F. Hill-Briggs [et al.] // Patient Prefer Adherence. - 2013. Aug 6-7 - P. $741-749$.

14. PajNok A. Cardiovascular Disease in Central and East Europe / A. PajNok, M. Kozela // Public Health Reviews 2012. - № 2. - Vol. 33. - P. 416-435.

15. Robbs L. Oestrogen and progestin increased urge and stress incontinence in postmenopausal women with coronary heart disease / L. Robbs // Evid. Based. Nurs. - 2006. - Vol. 9, № 3. - P. 84. 
16. The impact of health literacy on desire for participation in healthcare, medical visit communication, and patient reported outcomes among patients with hypertension / H. J. Aboumatar, K. A. Carson, M. C. Beach [et al.] // J. Gen Intern Med. - 2013. - Vol. 28 (11). - P. 1469-1544.

17. Yusuf S. Combination pharmacotherapy to prevent cardiovascular disease: present status and challenges / S. Yusuf // European Heart Journal. - 2014. - № 6. - Vol. 35. - P. 353-364.

\section{МЕДИКО-ОРГАНИЗАЦИОННЫЕ НЕДОСТАТКИ ПРОФИЛАКТИКИ БОЛЕЗНЕЙ СИСТЕМЫ КРОВООБРАЩЕНИЯ В УКРАИНЕ И ПУТИ ИХ РЕШЕНИЯ}

А.В. Коваленко, В.И. Клименко

Запорожский государственный медицинский университет, Украина

Цель: установить медико-организационные недостатки профилактики болезней системы кровообращения на региональном уровне и разработать пути их решения.

Материалы и методы. Проведен анализ состояния здоровья населения трудоспособного возраста по данным отчетов центров медицинской статистики и медико-социальной экспертизы Запорожской области; медико-социальный опрос 525 человек трудоспособного возраста и 100 врачей терапевтического профиля. В исследовании использованы библиосемантичний, медико-статистический, социологический методы.

Результаты. Доказано, что болезни системы кровообращения остаются значимой медико-социальной проблемой. Определена распространенность ведущих управляемых факторов риска среди населения трудоспособного возраста, которое страдает болезнями системы кровообращения. На примере гипертонической болезни, как наиболее распространенной нозологии, показана неэффективность профилактических мероприятий, а ведущим медико-организационным недостатком является недостаточный уровень информирования населения трудоспособного возраста о факторах риска болезней системы кровообращения, что приводит к ошибочному представлению о влиянии образа жизни на состояние здоровья.

Выводы. Стратегическим направлением усовершенствования организации профилактики болезней системы кровообращения на межсекторальном уровне должно стать объединение усилий общественных и религиозных организаций и медицинских учреждений.

КЛЮЧЕВЫЕ СЛОВА: болезни системы кровообращения, информационно-образовательное обеспечение, профилактика, население трудоспособного возраста.

\section{MEDICAL AND ORGANIZATIONAL DISADVANTAGES OF CIRCULATORY DISEASES PREVENTION IN UKRAINE AND WAYS OF THEIR OVERCOMING}

A.V. Kovalenko, V.I. Klimenko

Zaporozhye State Medical University, Ukraine

Purpose: to establish medical and organizational shortcomings of the cardiovascular diseases prevention at the regional level and to develop ways to overcome them.

Materials and methods. The analysis of health of the working age population according to the Centers of Health Statistics reports and medical and social examination of Zaporozhye region is carried out; medical and social survey of 525 people of working age and 100 doctors of therapeutic profile are conducted. Bibliosemantyck, medical and statistical, sociological methods are used.

Results. It is proved that cardiovascular diseases are significant medical and social problem. The prevalence of major operated risk factors among population of working age suffering from cardiovascular diseases was determined. In the case of hypertension as the most common nosology inefficiency of preventive measures is shown. In addition, a leading medical and organizational disadvantage is insufficient level of informing people of working age on risk factors for cardiovascular diseases that leads to false representation of the impact of lifestyle on health.

Conclusions. The strategical destination of cardiovascular diseases prevention improvement at intersectoral level should be the joint efforts of public and religious organizations and medical institutions.

KEY WORDS: cardiovascular diseases, informational and educational provision, prevention, workingage population.

Рукопис надійшов до редакції 09.11.2014 р.

\section{Відомості про авторів:}

Коваленко Андрій В'ячеславович - асистент кафедри організації охорони здоров'я, соціальної медицини та лікарсько-трудової експертизи Запорізького державного медичного університету; тел.: +38 (0612) 233-32-47. Клименко Вікторія Іванівна - д.мед.н., проф., завідувач кафедри організації охорони здоров'я, соціальної медицини та лікарсько-трудової експертизи Запорізького державного медичного університету; тел.: +38 (0612) 236-22-90. 